\title{
Examining the potential of natural gas demand-side measures to benefit customers, the distribution utility, and the environment: two case studies from Europe
}

\author{
Aníbal T. de Almeida ${ }^{\mathrm{a}, *}$, Ana Cristina Lopes ${ }^{\mathrm{b}}$, Anabela Carvalho ${ }^{\mathrm{c}}$, \\ Jorge Mariano $^{\mathrm{c}}$, Andreas Jahn ${ }^{\mathrm{d}}$, Michael Broege ${ }^{\mathrm{d}}$ \\ a Department of Electrical and Computer Engineering, Institute of Systems and Robotics, University of Coimbra, \\ PoloII, 3030-290 Coimbra, Portugal \\ ${ }^{\mathrm{b}}$ Escola Superior de Tecnologia, Instituto Politécnico de Tomar Quinta do Contador, Estrada da Serra, \\ 2300-313 Tomar, Portugal \\ c Instituto Superior de Engenharia de Coimbra Quinta da Nora, Apartado 10057, 3031-601 Coimbra, Portugal \\ d MVVInnoTec, Kurfurstendamm 199, D-10719 Berlin, Germany
}

Received 5 August 2003

\begin{abstract}
The aim of this paper is to demonstrate how integrated resource planning (IRP) oriented to the gas sector can be applied both in new networks and in mature networks, and to present the advantages of its application. One case study is described, in the western central region of Portugal, to illustrate the results of a pilot project on natural gas IRP implementation in a new network in the European Union (EU). The city of Burg, Germany, with a mature gas network with district heating was also analysed in terms of IRP potential. The most important phases of the integrated resource plan definition and implementation (especially those oriented to the demand-side) are presented, namely, the definition of the most efficient technologies (including solar energy), fuel-switching possibilities, a detailed study of the impacts in the economy, environment and society, and the policy incentives necessary to motivate the gas utility companies to perform IRP. In the main case study, the suggested implementation plan would lead to a reduction of around $4.7 \%$ in natural gas consumption. Additionally, $13.3 \%$ of cost-effective fuel switching from other competing forms of energy to natural gas can be achieved. A proposed EU energy services directive on mandatory energy-efficiency activities for gas and electricity distribution utilities in the EU, will promote the large-scale implementation of the proposed approach in Europe.
\end{abstract}

(C) 2003 Elsevier Ltd. All rights reserved.

\footnotetext{
* Corresponding author. Tel.: +351-239-796-218; fax: +351-239-406-672.

E-mail address: adealmeida@isr.uc.pt (A.T. de Almeida).
} 


\section{Introduction}

Since the early-1960s, natural gas consumption has been increasing very rapidly in Europe. In order to improve energy security, the European Commission has decided to develop a strategy plan concerned with the European Union (EU) supply-side policy. The role of natural gas is emphasised, since it provides better energy diversification. Additionally, when it is compared with competing forms of energy such as coal, oil, liquefied propane gas (LPG), or electricity produced in other fossil fuel-based power plants, natural gas causes less damage to the environment [1].

At present, most of the EU Member States are still dependent on external supplies for energy and besides the environmental issues, natural gas imports constitute a heavy burden to those countries. Natural gas consumption represents around $20 \%$ of the EU energy needs and all forecasts show natural gas consumption increasing in the years ahead. An increase in demand is also expected in all market segments, especially in power generation. This scenario shows that traditional planning techniques that concentrate on satisfying demand by increasing supply no longer fully respond to societal and environmental needs [1]. The integrated resource planning techniques that make rational economic assessment of the relative merits of new supply capacity and demand reduction programmes can lead to a maximisation of the utility, customer and societal benefits, if a suitable regulatory framework is approved [2].

There are very few studies on natural gas integrated resource planning (IRP). This type of planning methodology was primarily oriented to electricity utility companies [3]. One of the main goals of this study was to show that gas utility companies could greatly benefit from implementing this planning technique. Basically, IRP is a business-planning concept for energy companies, which seeks the least-cost combination of "traditional" supply options and new, usually distributed resources (particularly demand-side management (DSM), but also co-generation of heat and power (CHP) and renewable energy resources) [4]. IRP is based on a customer-oriented concept instead of focusing only on increasing sales. Among others, this constitutes one of the major barriers to the IRP implementation because energy companies are usually distrustful of this new planning methodology since, in principle, it may be responsible for significant sales reduction [5]. Only the support of an innovative energy policy may overcome this important barrier. It is essential to define a regulatory framework, which obliges the energy companies to perform IRP and also to define the appropriate incentive mechanisms to compensate the energy companies for the loss of revenue, and for the initial investments needed to perform DSM [6].

The natural gas IRP pilot action study was the result of a 2-year project in Germany and Portugal. This study, which was carried out under the European Union SAVE II programme, has fallen upon three economical sectors-industry, services, and residential sector, since they were likely to receive a large impact from the application of IRP methodology. Two different gas market structures were found in these case studies - a new and a mature market structure. The first one was concerned with the Portuguese gas market (the introduction of natural gas was carried out at the end of 1997), the latest was concerned with the German gas market. After defining the target region for each case study, eight different tasks were carried out as follows [1]: 
- Task 1 - Collection and update of supply and demand-side data for the gas sector;

- Task 2-List of energy-efficiency measures to be implemented and evaluation of their costeffectiveness;

- Task 3-Evaluation of fuel switching opportunities in different sectors;

- Task 4-Development of economic scenarios;

- Task 5-Energy forecast;

- Task 6-Integration of demand-side and supply-side options;

- Task 7-Evaluation of the effects of the measures;

- Task 8-Definition of the promoting activities needed to implement the natural gas IRP for each case study.

This paper presents the case study of the western central region of Portugal, which constituted the main case of the pilot study on natural gas IRP. The most relevant results of a second case study for the city of Burg, Germany, are also presented.

The presentation of the main results of this study follows the structure presented below:

- In Section 2, a characterisation of the natural gas market in the western central region of Portugal is carried out. Several relevant indicators are presented, such as area, population, and energy consumption of all competing forms of energy for each economy sector.

- In Sections 3 and 4, a set of possible measures to be implemented in the demand-side is presented. Two different types of measures are analysed, namely, measures to increase natural gas conversion efficiency, which are presented in Section 3, and fuel-switching measures from other competing forms of energy to natural gas, which are presented in Section 4. In both cases, a technical, economical and environmental analysis was carried out for each measure.

- In Section 5, an integration of demand- and supply-side options is carried out. The results of an integration plan development are presented. This implementation plan is based in two packages of measures, which are presented in Sections 3 and 4. The main purpose of this section is to allow gas utility companies, as well as other market and government actors, the possibility to provide cost-effective options to consumers.

- In Section 6, the economic and environmental impacts on consumers and the gas utility company, which would result from the implementation of the developed integrated plan, are presented.

\section{Characterisation of the natural gas market in the western central region of Portugal}

The introduction of natural gas in several European countries emerged as an answer to several significant political objectives, which were concerned not only with energy but also with environment, industrial policy, and regional development. The introduction of natural gas was also used as an instrument to promote the improvement of the energy balance, since some EU Member States were greatly dependent on oil. Natural gas supply started to be introduced in Portugal at the end of 1997. Since no relevant consumption was carried out during 1997, 1998 was considered as the reference year for natural gas [1]. 
Table 1

1997 energy balance

\begin{tabular}{lclrlll}
\hline Sectors & $\begin{array}{l}\text { Electricity } \\
\text { (toe) }\end{array}$ & $\begin{array}{l}\text { LPG } \\
\text { (toe) }\end{array}$ & $\begin{array}{l}\text { Fuel oil } \\
\text { (toe) }\end{array}$ & $\begin{array}{l}\text { Biomass } \\
\text { (toe) }\end{array}$ & $\begin{array}{l}\text { Others }^{\text {a }} \\
\text { (toe) }\end{array}$ & $\begin{array}{l}\text { Total } \\
\text { (toe) }\end{array}$ \\
\hline Industry & 250000 & 287000 & 568000 & 435000 & 238000 & 1778000 \\
Services & 76000 & 50000 & 28000 & 3600 & - & 157600 \\
Households & 111000 & 78500 & 0 & 129000 & - & 318500 \\
Other sectors & 19000 & - & 1580 & - & 1027000 & 1047580 \\
Total (by energy resource) & 456000 & 415500 & 597580 & 567600 & 1265000 & 3301680 \\
\hline
\end{tabular}

Sources: DGE, Directorate General of Energy; EDP, Electricity of Portugal.

${ }^{a}$ The energy types considered are coal, gas oil/diesel, and oil.

${ }^{\mathrm{b}}$ Remaining sectors: agriculture, transports (includes all the transports related with all economic sectors), etc.

The region in concern is located in the western central part of Portugal, with a total area of $10282 \mathrm{~km}^{2}$ and a population of $1530000^{1}$. Statistics show that in recent years energy consumption in this region is rapidly increasing. This is mainly due to the growth of the economy, especially in the service and residential sectors. The energy consumption increase in these sectors is related to a search for better comfort levels as a result of higher disposable income. Table 1 presents the 1997 energy balance for this region. The production of electricity is not represented, since only a modest percentage of electricity (hydroelectric power plants) was produced in the region [1].

The significant energy consumption presented for "other sectors" is mainly due to the transportation sector which consumes a great deal of diesel and gasoline. The natural gas consumption for 1998 is presented in Table 2 [1].

\section{Measures to increase the natural gas conversion efficiency}

In this section, a set of gas conservation measures to be implemented on the demand-side is presented. A technical, economical and environmental analysis was carried out for each measure.

Portuguese consumers are buying natural gas equipment for the first time, because the natural gas market is very recent. For this reason, the acquisition of the most efficient equipment must be encouraged. In order to establish the most appropriate energy-efficiency measures, it is essential to consider the reality in which the natural gas market is inserted, i.e. to know accurate consumption data as well as consumers' behaviour.

The cost-effectiveness for each measure was assessed taking into account the investment difference between a conventional and a more efficient technology. The measures that seem more appropriated for the natural gas end-uses are presented in the following section.

\footnotetext{
${ }^{1}$ Source: INE—National Institute of Statistic.
} 
Table 2

1998 natural gas consumption

\begin{tabular}{lccc}
\hline Sector & LusitaniaGás (toe) & TransGás (toe) $^{\mathrm{b}}$ & Total $^{\mathrm{a}}$ \\
\hline Industry & 13907 & 158662 & 172569 \\
Services & 2234 & 0 & 2234 \\
Households & 1487 & 0 & 1487 \\
Total & 17628 & 158662 & 176290 \\
\hline
\end{tabular}

Source: LusitaniaGás and TransGás.

${ }^{a}$ LusitaniaGás is the western central region distribution utility. The natural gas supply $/ \operatorname{costumer}<10000 \mathrm{~m}^{3} / \mathrm{year}$.

b TransGás is the national transport utility. The natural gas supply/costumer $>10000 \mathrm{~m}^{3} /$ year.

\subsection{Measure development}

\subsubsection{Measure 1: high-efficiency wall heaters}

The Portuguese climate is characterised by mild weather conditions, and only 3-4 months of the year may be classified as cold months. In most residences (and also in some services), space heating is carried out through individual electric space heaters, and in some cases, there is not space heating at all. This leads to situations of severe discomfort during the coldest period. Therefore, the use of high-efficiency gas wall heaters may be appropriate to this scenario, since its investment cost is modest when compared to the investment necessary to install a central space heating system. Two technologies of this type were considered for this analysis, namely, a wall heater with a natural convection unit and a wall heater with a forced air unit. The natural convection wall heaters are not as efficient as forced air wall heaters. The first one is able to reach efficiency levels of around $70 \%$ while the other one can reach an efficiency level of more than $85 \%$. The cost-effectiveness analysis of this measure was carried out, assuming that a typical Portuguese family would have to choose between the most efficient technology (also the most expensive) and the least efficient. When observing Table 3, it is possible to conclude that the choice of a forced air wall heater may be classified as cost-effective.

\subsubsection{Measure 2: electronic thermostats}

An efficient thermostat should be simple to operate (with a friendly interface), electronic rather than electromechanical, and programmable. This measure consists in the substitution of a conventional thermostat (electromechanical thermostat) with an electronic one, assumed that

Table 3

Economical and environmental impact comparison between the two types of air wall heaters

\begin{tabular}{lllc}
\hline & $\begin{array}{l}\text { Reduction of gas consumption } \\
\text { and } \mathrm{CO}_{2} \text { emissions (\%) }\end{array}$ & Investment by unit (€) & Payback (years) \\
\hline $\begin{array}{l}\text { With forced air units } \\
\text { With natural convection }\end{array}-$ & 670 & - \\
units & $13 \%$ & 540 & - \\
Comparison & & 130 & 2.8 \\
\hline
\end{tabular}


the space heating equipment was working at a maximum load during $12 \mathrm{~h}$, in 4 months of the year (considered as winter months), and at a comfort temperature of $22{ }^{\circ} \mathrm{C}$ that should be maintained during these hours. The main idea was to programme the electronic thermostat so as to reduce temperature to $18{ }^{\circ} \mathrm{C}$ during $6 \mathrm{~h}$ (of the $12 \mathrm{~h}$ ). Finally, energy savings of around $2.39 \times 1^{-5}$ toe $(1 \mathrm{Mj})$ per each ${ }^{\circ} \mathrm{C}$ of temperature reduction were taken into account. The substitution of a conventional thermostat with an electronic one may be classified as a cost-effective measure since the simple payback is very reasonable (around 2 years). The results of this analysis are presented in Table 4.

\subsubsection{Measure 3: low-flow showerheads}

A large percentage of residential energy consumption is related to water heating. A low-flow showerhead mixes air into the water stream, providing the same level of comfort as a regular showerhead. Some low-flow showerheads also come with a shut-off valve, which makes it easy to turn off the water while soaping up. A low-flow showerhead will reduce the water consumption and consequently the energy consumption. Savings for low-flow showerheads were estimated based on the results presented by the Pacific Gas and Electric (PG\&E) [7] and South California Gas (SCG) [8], who estimate average savings that vary from 5\% to $10 \%$. According to these values, and bearing in mind that the Portuguese weather is similar to the California weather, it was assumed that low-flow showerheads would have an energy saving potential of $7.5 \%$.

\subsubsection{Measure 4: high-efficiency water heaters (with the possibility of being solar assisted)}

Portugal has a high potential for solar energy. However, this energy resource is used in a very limited way. Due to this reason, an implementation of a high-efficiency water heating system with the possibility of being solar assisted was analysed. It is important to note that in Portugal, solar water heaters could typically supply about $75 \%$ of the residential energy water heating needs.

This measure is far from being cost-effective for Portugal. In fact, the investment cost is too high, which does not allow an attractive payback period. Since this measure has a high potential of application, but is difficult to apply, at least on a large scale, financial/tax incentives should be considered. The main results of the economical and environmental impact analysis of the three last measures are presented in Table 4.

Table 4

Results of the economical and environmental impact analysis per family

\begin{tabular}{|c|c|c|c|c|c|c|}
\hline & $\begin{array}{l}\text { Natural gas con- } \\
\text { sumption per fam- } \\
\text { ily (toe/year) }\end{array}$ & $\begin{array}{l}\text { Natural gas sav- } \\
\text { ings per family } \\
\text { (toe/year) }\end{array}$ & $\begin{array}{l}\text { Reduction of natural } \\
\text { gas consumption and } \\
\mathrm{CO}_{2} \text { emissions }(\%)\end{array}$ & $\begin{array}{l}\text { Cost of the saved } \\
\text { energy by family }(€)\end{array}$ & $\begin{array}{l}\text { Investment } \\
(€)\end{array}$ & $\begin{array}{l}\text { Payback } \\
\text { (year) }\end{array}$ \\
\hline Measure 2 & 0.2 & 0.05 & 25.9 & 34.5 & 67 & 1.9 \\
\hline Measure 3 & 0.14 & 0.01 & 7.5 & 6.7 & 12.1 & 1.8 \\
\hline Measure 4 & 0.16 & 0.12 & 75.0 & 78.7 & 1247 & 15.8 \\
\hline
\end{tabular}




\subsubsection{Measure 5: use of heat protection glazing and sealing of joints}

Up to $50 \%$ of all heat losses escape to the outside through windows. Since many windows need urgent repair, there is the possibility to substitute them with new ones, in order to reach a better comfort (thermal and acoustical), and less heat losses. However, the cost of new windows is relatively high so the measure is at the edge of economic feasibility. The aim of this measure is to fill the small gap to economic efficiency and to accelerate the replacement of old windows. With this measure, around $20 \%$ of space conditioning heat demand can be saved.

\subsubsection{Measure 6: modernisation of heating equipment using condensing boilers}

Condensing boilers offer an energy efficiency improvement over conventional designs. They extract more heat from fuel. Burning $1 \mathrm{~m}^{3}$ of natural gas produces $10.1 \mathrm{~kW} \mathrm{~h}$ of available heat. However, by condensing all of the water steam contained in the flue gas, about $1.6 \mathrm{~kg}$ of water would be produced and a further $1.2 \mathrm{~kW} \mathrm{~h}$ of heat could be released in the form of latent heat. When this heat is recovered, the efficiency of the boiler can be increased by up to $11 \%$ based on the net calorific value. Condensing boilers are manufactured with output capacities ranging from $6 \mathrm{~kW}$ for individual dwellings, to over $2 \mathrm{MW}$ for large buildings such as hospitals.

A comparison of different condensing boiler projects showed payback periods from 1 to 4 years, depending on the power rating and on the amount of heat supplied. Condensing boilers produce the lowest emissions of air pollutants such as nitrogen oxides because most of them are trapped in the condensate. The carbon dioxide emissions are $11 \%$ lower than in conventional gas boilers due to better energy efficiency.

\section{Evaluation of fuel switching opportunities in the different sectors}

Like other DSM measures, equipment choices involving the substitution of one fuel source by another can be evaluated as potential DSM resource opportunity in terms of their potential advantages to customers, utilities, and society [1]. This section focuses on fuel switching of electricity, oil, diesel, and LPG to natural gas. For each type of load, where natural gas can compete in a cost-effective way with other energy sources, an analysis of the switching potential was carried out. Cost-effectiveness of fuel switching and reduction of emissions were considered in the development of each measure.

Gas load management options were not considered since the existing network still has plenty of spare capacity. The "take or pay" gas supply contract, with the exporters of natural gas, also encourages an effort towards gas fuel switching. However, the rapid expansion of electric generation with combined-cycle gas turbines (in $2005,70 \%$ of the natural gas will be used for electricity generation) means that the minimum purchase quantities have been met just by this type of use. In these conditions, demand-side natural savings can lead to potentially significant financial savings.

\subsection{Fuel switching in the industrial sector: Natural gas co-generation}

Natural gas co-generation is probably the option with the most significant impact when switching from other fuels to natural gas. Gas fired co-generation power plants are one of the best options available to decrease greenhouse gas emissions. When gas fired co-generation 
plants replace coal fired condensing electricity power plants, some $70-80 \%$ of the $\mathrm{CO}_{2}$-emissions can be saved. In Portugal, the economical importance of co-generation is obvious; since $60 \%$ of the electricity production is carried out with fossil fuel (such as coal and fuel oil) based power plants, with an energy efficiency performance around $35-40 \%$. With co-generation, it would be possible to achieve a combined efficiency of up to $80 \%$, if an appropriate thermal load is coupled to the plant.

The economical impact of switching fuel oil to natural gas in co-generation power plants with values up to $5 \mathrm{MW}$ of installed power is analysed. The economical and environmental impact analysis may be observed in Tables 5 and 6. Co-generation power plants with 2.8 and $4.5 \mathrm{MW}$ of installed power were considered for this analysis.

Table 6 shows that switching fuel oil to natural gas reduces carbon dioxide emissions by $27 \%$. The $\mathrm{SO}_{2}$ emission levels would also decrease significantly. At present, due to relatively large gas costs, switching fuel oil to natural gas in co-generation power plants does not bring any economic benefit. However, the environmental impact analysis showed that switching from fuel oil to natural gas would contribute significantly to carbon dioxide and other greenhouse gas emission reduction.

\subsection{Fuel switching in households}

\subsubsection{Gas water heater}

A large percentage of Portuguese families use either an electric water heater or a LPG gas heater. For this reason, switching from an electric water heater, or a LPG gas heater, to a natural gas heater is suggested. A natural gas heater has a typical efficiency of $75 \%$. Table 7 and Table 8 show the economical and environmental impact analysis. The average unit prices of natural gas, LPG and electricity, for the second quarter of 2000, were taken into account. Switching from electricity to natural gas (and to a smaller extent in relation to LPG) results in a large reduction of carbon dioxide emission.

\subsubsection{Gas space heater}

Residential space heating in Portugal is essentially provided through single room units, which use electricity, LPG, or biomass. Using the same criteria of the previous case, and assuming that $37 \%$ of families use individual electric space heaters, 20\% use LPG individual space heaters and $43 \%$ use biomass space heaters, it is possible to estimate energy consumption per family. Table 9 shows the economical impact analysis.

Table 9 shows that switching from electricity to natural gas has the greatest economical impact, resulting in a cost reduction of $19 \%$. Switching from LPG to natural also has a significant

Table 5

Economical impact analysis of switching fuel to natural gas

\begin{tabular}{lllll}
\hline Installed power & $\begin{array}{l}\text { Natural gas } \\
\left(\mathrm{kg} / \mathrm{kW} \mathrm{h} \mathrm{h}_{\text {elect }}\right)\end{array}$ & $\begin{array}{l}\text { Fuel oil } \\
\left(\mathrm{kg} / \mathrm{kW} \mathrm{h} \mathrm{h}_{\text {elect }}\right)\end{array}$ & Cost $\left(€ / \mathrm{kW} \mathrm{h} \mathrm{h}_{\text {elect }}\right)$ & Fuel oil \\
\hline $2.8 \mathrm{MW}$ & 0.22 & 0.19 & 0.029 & 0.03 \\
$4.5 \mathrm{MW}$ & 0.21 & 0.19 & 0.028 & 0.029 \\
\hline
\end{tabular}


Table 6

Environmental impact analysis of switching fuel to natural gas

\begin{tabular}{ll}
\hline & $\mathrm{Kg} \mathrm{CO}_{2} / \mathrm{kW} \mathrm{h}_{\text {elect }}$ \\
\hline Fuel oil & 0.68 \\
Natural gas & 0.5 \\
Saved emissions & 0.18 \\
$\%$ reduction & $27 \%$ \\
\hline
\end{tabular}

economical impact, leading to a reduction of around 13\% of energy costs. Switching from biomass to natural gas shows an increase of around $10 \%$ of energy cost. Table 10 illustrates the environmental impact analysis.

Concerning electricity and LPG space heaters, the reduction of the carbon dioxide emissions, as in the case of gas water heater, is very significant. It is important to point out that the combustion of biomass does not contribute to net $\mathrm{CO}_{2}$ emissions, therefore, the replacement of biomass with natural gas would lead to an increase of $\mathrm{CO}_{2}$ emissions.

\section{Integration of demand-side and supply-side options}

This section presents the results of the development of an integration plan, which essentially allows the possibility of gas utilities, as well as other market and government actors in providing cost-effective DSM options to consumers. A successful implementation plan should optimise the integration of all factors (economical, societal, environmental, political, etc.).

The basis of this implementation plan is structured according to the measures presented in the previous sections. The liberalisation of gas markets has enhanced the necessity of establishing a deeper relationship between gas utility and consumers. Gas utility should be engaged in providing energy services to consumers instead of just selling $\mathrm{m}^{3}$ of natural gas. Utility behaviour centred on the consumer will be a competitive factor for gas utilities and the main objective is still aimed at achieving the highest level of profit [6].

\subsection{Definition of reward mechanisms and financial mechanisms to gas utilities}

Distribution utilities under restructuring face significant barriers and disincentives for energy efficiency. Without regulatory intervention, they will generally seek to promote increased sales and will be averse to energy efficiency programmes. At this moment, there is a proposal for an

Table 7

Water heating economical impact analysis (energy cost/year) per family

\begin{tabular}{lllll}
\hline Type of switching & $\begin{array}{l}\text { Initial energy } \\
(€ / \text { year })\end{array}$ & $\begin{array}{l}\text { Natural gas } \\
(€ / \text { year })\end{array}$ & $\begin{array}{l}\text { Cost saving } \\
(€ / \text { family } \times \text { year })\end{array}$ & $\begin{array}{l}\text { Relative cost saving } \\
(\%)\end{array}$ \\
\hline $\begin{array}{l}\text { Electricity to natural } \\
\text { gas }\end{array}$ & 124 & 94 & 30 & 24.30 \\
\begin{tabular}{l} 
LPG to natural gas \\
\hline
\end{tabular} & 108 & 94 & 14 & 13 \\
\hline
\end{tabular}


Table 8

Water heating environmental impact analysis $\left(\mathrm{kg} \mathrm{CO}_{2} /\right.$ year $)$ per family

\begin{tabular}{lllll}
\hline Type of switching & $\begin{array}{l}\text { Initial energy } \\
\text { (ton } \mathrm{CO}_{2} / \text { year) }\end{array}$ & $\begin{array}{l}\text { Natural gas } \\
\text { (ton } \mathrm{CO}_{2} / \text { year) }\end{array}$ & $\begin{array}{l}\text { Saved emissions } \\
\left(\mathrm{kg} \mathrm{CO}_{2} / \text { family } \times \text { year) }\right.\end{array}$ & $\begin{array}{l}\text { Relative saved emis- } \\
\text { sions }(\%)\end{array}$ \\
\hline Electricity to natural gas & 0.5 & 0.32 & 180 & 36 \\
LPG to natural gas & 0.4 & 0.32 & 80 & 20 \\
\hline
\end{tabular}

EU Directive on Energy Services concerned with the regulatory framework on these matters. Different regulatory strategies can deal with different aspects of the barriers and disincentives faced by distribution utilities. In order for a utility to invest in energy efficiency, a fair mechanism must be assured so as to recover its prudently incurred costs, as well as some rewarding mechanisms [6]. In the following sections, possible financial mechanisms, and reward mechanisms are presented.

\subsubsection{Financial mechanisms}

There is a variety of possible financial mechanisms that can be applied, and are described in this section. A public benefit charge consists in a method of raising funds from the operation of the gas market, which can be directed into energy-efficiency activities, and other public benefit purposes (e.g. promotion of renewable energies). A public benefit charge (also often known as a system benefit or pipes charge) is a charge or tax imposed on participants in the gas market. An energy efficiency public benefit charge can generate funds for several types of organisations to implement new energy efficiency programmes, either to maintain, or increase the scope of existing energy efficiency programmes. It can also be linked to achieving specific energy efficiency goals [9]. The application of the public benefit charge requires a previous and clear definition of whom is charged and how much. Some options include: volumetric surcharges $\left(€ / \mathrm{m}^{3}\right.$, which consist of a surcharge applied to the $\mathrm{m}^{3}$ sold) $)^{2}$, surcharges based on the total gas bill (a percentage applied to the total bill), and a uniform charge levied on all (franchise) customers [10]. Concerning the surcharges described above, the one that appears to be fairer is the volumetric surcharge, since it is applied to the total $\mathrm{m}^{3}$ sold, which are directly associated with the amount of environmental emissions. The pipes charge may cause problems of equity among all customers, because small and large customers will be paying the same [10].

Table 9

Space heating economical impact analysis $(€ /$ year) per family

\begin{tabular}{lllcc}
\hline Type of switching & $\begin{array}{l}\text { Initial energy } \\
(€ / \text { year })\end{array}$ & $\begin{array}{l}\text { Natural gas } \\
(€ / \text { year })\end{array}$ & $\begin{array}{l}\text { Cost saving } \\
(€ / \text { family } \times \text { year })\end{array}$ & $\begin{array}{l}\text { Relative cost sav- } \\
\text { ing }(\%)\end{array}$ \\
\hline Electricity to natural gas & 165 & 134 & 31 & 19 \\
LPG to natural gas & 154 & 134 & 20 & 13 \\
Biomass to natural gas & 122 & 134 & -12 & -10 \\
\hline
\end{tabular}

\footnotetext{
${ }^{2} €$ is the EU currency unit. The exchange rate in September 2003 was $€ 1=$ US $\$ 1.07$
} 
Table 10

Space heating environmental impact analysis $\left(\mathrm{kg} \mathrm{CO}_{2} /\right.$ year $)$ per family

\begin{tabular}{lllcl}
\hline Type of switching & $\begin{array}{l}\text { Initial energy (ton } \\
\mathrm{CO}_{2} / \text { year) }\end{array}$ & $\begin{array}{l}\text { Natural gas (ton } \\
\left.\mathrm{CO}_{2} / \text { year }\right)\end{array}$ & $\begin{array}{l}\text { Saved emissions } \\
\left(\mathrm{kg} \mathrm{CO}_{2} / \text { family } \times \text { year }\right)\end{array}$ & $\begin{array}{l}\text { Relative saved } \\
\text { emissions (\%) }\end{array}$ \\
\hline Electricity to natural gas & 0.7 & 0.5 & 230 & 33 \\
LPG to natural gas & 0.6 & 0.5 & 102 & 18 \\
Biomass to natural gas & 0 & 0.5 & -500 & Net increase $^{\mathrm{a}}$ \\
\hline
\end{tabular}

${ }^{\text {a }}$ The $\mathrm{CO}_{2}$ emission factor due to biomass combustion is considered null, based on a renewable use of biomass.

Regulatory agencies may allow gas utilities to charge customers for DSM or energy efficiency programmes, which are offered and taken by the customers. In some places, gas utilities are required by law to carry out such programmes [11].

\subsubsection{Incentive policies for gas distribution utilities performing DSM actions}

In order to motivate the distribution companies (DISCOs) in promoting DSM programmes, it is necessary to analyse the impacts derived from the application of the DSM programme on a utility. Cost of the application of a DSM programme is beyond the cost of application of the programme itself. Since the objective of a DSM programme is directly connected to decrease in gas sales, the potential loss to a utility of a DSM programme is described in Eq. (1) [6]:

\section{Potential Loss to a Utility of DSM Programme \\ $=$ Cost of DSM Programme + Lost Net Revenue}

A utility will not be motivated when applying DSM programmes if profits from this implementation are not at least higher than losses (Cost of DSM Programme + Lost Net Revenue). Thus, fair incentive policies have to be created in order to encourage utilities in the implementation of DSM programmes. A common regulatory strategy of IRP/DSM is the use of specific financial incentives and/or penalties to encourage utility involvement in energy

Table 11

Structure of gas supply cost for industry

\begin{tabular}{lll}
\hline Supply cost per year & $€ /$ year & $€ / \mathrm{m}^{3} \mathrm{NG}$ \\
\hline Import price & n.a. & n.a. \\
Purchase from wholesaler & 8180181 & 0.170 \\
Network cost & 1762897 & 0.021 \\
Pipelines & 1324464 & 0.028 \\
Stations & n.a. & n.a. \\
Pumping & n.a. & n.a. \\
Overhead costs & 1016862 & 0.021 \\
Administration & 968363 & 0.020 \\
Planning, maintenance & n.a. & n.a. \\
Other cost & 86158 & 0.002 \\
& & \\
Total & 13338926 & 0.262 \\
\hline
\end{tabular}

Source: LusitaniaGás. 
efficiency. A possible criterion consists in rewarding utility profits at a percentage of net savings of DSM programmes [11].

An even simpler method is to negotiate annual efficiency targets with utilities and tie specified awards to the achievement of those targets. This has the advantage of avoiding arguments over the proper calculation and application of rate of return [11]. In Europe, several countries give out large subsidies based on saved carbon dioxide emissions (typical price premiums are in the range of 2-4 Euro cents $/ \mathrm{kW} \mathrm{h}$ ) to producers of renewable energy. In terms of environmental impact, a $\mathrm{kW}$ h saved has a similar impact as a $\mathrm{kW}$ h produced by renewable energy [6].

Since the distribution companies can be rewarded, somehow, on their performance concerning the application of DSM programmes, they would also have certain obligations regarding the application of those programmes, such as to prepare a comprehensive assessment of energyefficiency programmes, its cost-effectiveness and saving potentials $\left(\mathrm{m}^{3}\right.$ of gas, tons of $\left.\mathrm{CO}_{2}\right)$, and to have a minimum commitment level in terms of DSM effort as a function of sales (e.g. levels of DSM investments in the range of $1-3 \%$ of sales) [6].

\subsection{Benefits of fuel-switching measures}

The natural gas market is very recent in Portugal and the existing network has plenty of spare capacity. The "take or pay" gas supply contract further encourages gas utilities towards the implementation of fuel-switching measures. This means that at present, it is not necessary to define financial mechanisms, or reward mechanisms to motivate gas utilities in performing fuel switching from other forms of competing energies to natural gas. The fuel switching benefits for the different stakeholders include:

- Consumers - switching from other forms of competing energies to natural gas may bring about significant economic benefits. However, the benefit is also dependent on the efficiency of end-use technology. Some fuel switching examples, including associated cost savings, may be observed in Tables 7 and 9.

- Utility - a significant increase in gas sales may be considered as the main benefit of fuel switching. This situation is even more relevant because there is plenty of natural gas spare capacity.

- Environment - since in most situations, the use of natural gas may lead to a reduction of greenhouse gas emissions, the environmental benefit is very clear.

\subsection{Demand-side screening analysis}

This section includes the demand-side screening analysis which is the initial step that gas utilities should do in determining potentially cost-effective and attractive demand-side measures.

\subsubsection{Supply-side}

The western central region case study was essentially based on a definition of an integration plan oriented to LusitaniaGás - the region gas distribution utility. Before defining the measures and the promotion activities that are going to be integrated, it is relevant to know, with a good 
Table 12

Cost of expansion

\begin{tabular}{llllll}
\hline Cost of expansion & Units & \multicolumn{1}{l}{1998} & \multicolumn{1}{l}{2000} & \multicolumn{1}{l}{2003} & \multicolumn{1}{l}{2010} \\
\hline Gas supply, expected demand & $\mathrm{m}^{3} /$ year & 19465000 & 80617000 & 111673000 & 162701000 \\
Capacity & $\mathrm{m}^{3}$ & 20602000 & 81012000 & 112805000 & 164330000 \\
Contracted gas deliveries from whole- & $\mathrm{m}^{3}$ /year & 20602000 & 81012000 & 112805000 & 164330000 \\
saler & $\mathrm{m}^{3}$ & 1137000 & 395000 & 1132000 & 1629000 \\
Free capacities & &
\end{tabular}

Source: LusitaniaGás.

Table 13

Planned investments

\begin{tabular}{|c|c|c|c|c|c|}
\hline Investments planned & Units & 1998 & 2000 & 2003 & 2010 \\
\hline $\begin{array}{l}\text { Other costs related to expan- } \\
\text { sion }\end{array}$ & $€ /$ year & 1010070 & 3412675 & 20950 & 10974 \\
\hline Cost of expansion & $€ /$ year & 28484246 & 34524281 & 5426422 & 2135354 \\
\hline Cost of expansion $/ \mathrm{m}^{3} \mathrm{NG}$ & $€ / \mathrm{m}^{3} \mathrm{GN}$ & 1.463 & 0.428 & 0.049 & 0.013 \\
\hline
\end{tabular}

Source: LusitaniaGás.

level of precision supply costs, costs of expansion and planned investments of LusitaniaGás. Tables 11-13 present those values, which refer to the second quarter of 2000 .

The comparison between the supply costs, expressed in the previous tables, and the costs associated with the implementation of DSM and fuel switching measure actions, is the key economic issue of this evaluation.

\subsubsection{Demand-side}

Table 14 presents the list of DSM measures that seemed to be the most appropriated for the western central region case study, together with the list of promotion activities necessary to motivate consumers to adopt DSM options [12]. Also, the incentives necessary to implement those measures, together with the energy savings/switched, resulting from the implementation of the plan oriented towards the western central region gas distribution utility, are presented in Table 14.

LusitaniaGás would carry out most of the measures ${ }^{3}$ with the exception of the electric heat pump (measure 7), which does not make sense in this context. Most of the measures are intended for the residential sector, with the exception of co-generation. However, almost all the measures presented for the residential sector may be easily expanded to the service sector. Applying co-generation in non-residential buildings is generally not economically cost-effective at this moment. Natural gas price is too high to balance the necessary investment, and due to mild weather in the region, thermal loads are generally small. However, in health and hotel subsectors, with the introduction of trigeneration (both heating and cooling) technologies in the

\footnotetext{
${ }^{3}$ The investment necessary for each measure is carried out by the participants and the gas distribution utility.
} 
Table 14

Integration of demand- and supply-side measures

\begin{tabular}{lllrrrrr}
\hline Measures & $\begin{array}{l}\text { Promotion } \\
\text { activities }\end{array}$ & $\begin{array}{l}\text { Market } \\
\text { penetration } \\
(\%)\end{array}$ & $\begin{array}{l}\text { No. of } \\
\text { house- } \\
\text { holds/ } \\
\text { industries }\end{array}$ & $\begin{array}{l}\text { Aggregate } \\
\text { investment }^{\mathrm{a}} \\
(€ / \text { measure })\end{array}$ & $\begin{array}{l}\text { Saved energy/ } \\
\text { switched energy } \\
(\mathrm{MW} \text { h) }\end{array}$ & $\begin{array}{l}\text { Cost/effect } \\
(€ / \mathrm{MW} \mathrm{h} \\
\text { gas })\end{array}$ & $\begin{array}{l}\text { Combined saved } \\
\text { energy/switched } \\
\text { energy (MW h) }\end{array}$ \\
\hline 1 & $1+2+3$ & 2.5 & 5000 & 554300 & 6900 & 80.5 & 6340 \\
2 & $4+2$ & 50 & 100000 & 836500 & 11700 & 59.4 & 11700 \\
3 & $2+3$ & 15 & 30000 & 624000 & 18000 & 34.7 & 18000 \\
4 & 2 & 2.5 & 5000 & 88300 & 2300 & 38 & 1730 \\
5 & $2+4+3$ & 15 & 30000 & 3240000 & 48900 & INF & 48900 \\
6 & $2+4+3$ & 10 & 20000 & 4530000 & 46500 & INF & 46500 \\
7 & $1+2+3$ & 2.5 & 5000 & 243000000 & 0 & INF & 0 \\
8 & 2 & 21 ceramic industries & 60000 & 122000 & INF & 122000
\end{tabular}

Caption: List of DSM measures: 1, solar water heating assisted by natural gas back-up; 2, low-flow showerheads; 3 , electronic thermostat; 4 , use double glazing and protection of joints; 5 , gas water heater; 6 , gas space heater; 7 , electric heat pump; 8, co-generation in industry. List of promotion activities: 1, leasing; 2, marketing (which includes: general advertising /leaflets; free phone; regional energy information centres; energy bus; walk-through and comprehensive audits; etc.); 3 , free installation/direct dealer discount; 4, donation/direct buyer discount.

${ }^{a}$ The investment presented in this table is totally carried out by LusitaniaGás, with the exception of measure 7 . The investment carried out by participants is not included.

market, the payback period may become attractive. This may suggest that if natural gas prices came down, the implementation of co-generation in some of the institutions belonging to those sub-sectors would be economically viable.

The DSM programme presented in Table 14 is supposed to be applied in 1 year. The penetration rates are relatively high, because they are only referred to the natural gas consumer's universe. For instance, although measure 2 presents a market penetration rate of 50\%, its real market penetration rate (if all western central region households are considered) is below $20 \%$. This result can be achieved if there is a suitable utility marketing effort combined with incentives (e.g. giving low-flow showerheads).

The calculation of the combined saved energy/switched energy was carried out taking into account the inter-active effects of the savings that target the same end-use.

These results are shown in Table 14 (column combined saved energy/switched energy) ${ }^{4}$. The total energy savings in the residential sector are $4.7 \%$.

\subsubsection{Comparative analysis of DSM measures}

Table 15 presents the comparison between supply-side and demand-side costs for the different measures. The comparison was carried out based on two different approaches: the first one compares the supply cost of natural gas with the cost of saved energy for each gas conservation

\footnotetext{
${ }^{4}$ In a household with a water-heating energy consumption of 0.16 toe, implementation of measure 2 would lead to a reduction of energy consumption of 0.012 toe. If measure 1 is also applied in the same household, an initial energy consumption of 0.14 toe has to be considered (instead of 0.16 toe). This calculation also considered the market penetration rate for each measure.
} 
Table 15

Comparison between supply-side and demand-side costs

\begin{tabular}{|c|c|c|c|c|c|}
\hline \multirow[t]{2}{*}{ Measures } & \multirow[t]{2}{*}{$\begin{array}{l}\text { Average lifetime } \\
\text { (years) }\end{array}$} & \multicolumn{2}{|c|}{$\begin{array}{l}\text { Comparison between NG cost for } \\
\text { the residential sector and cost of } \\
\text { saved energy (CSE) }\end{array}$} & \multicolumn{2}{|c|}{$\begin{array}{l}\text { Comparison between the utility } \\
\text { avoided supply costs and the costs of } \\
\text { DSM programme }\end{array}$} \\
\hline & & $\begin{array}{l}\text { NG customer cost } \\
\left(€ / \mathrm{m}^{3} \mathrm{NG}\right)\end{array}$ & $\operatorname{CSE}\left(€ / \mathrm{m}^{3} \mathrm{NG}\right)$ & UASC $(€)$ & $\begin{array}{l}\text { Cost of DSM pro- } \\
\text { gramme }(€)\end{array}$ \\
\hline 1 & 20 & 0.61 & 0.67 & 1830000 & 554300 \\
\hline 2 & 10 & 0.61 & 0.097 & 1920000 & 836500 \\
\hline 3 & 15 & 0.61 & 0.12 & 3970000 & 624000 \\
\hline 4 & 30 & 0.61 & 0.64 & 751000 & 88300 \\
\hline Total & & 0.61 & 0.28 & 8250000 & 2100000 \\
\hline
\end{tabular}

measure; the second approach compares the gas utility avoided supply costs with the cost of the DSM programme.

The cost of saved energy (CSE) was determined according to Eq. (2):

$$
\mathrm{CSE}=\frac{\mathrm{CI} \times i}{\mathrm{SE} \times\left(1-(1+i)^{-n}\right)}
$$

where $\mathrm{CI}$ is the total cost of implementation of the measures $(€) ; i$ is the interest rate (5\%); SE is the saved energy $\left(\mathrm{m}^{3} /\right.$ year); and $n$ is the average lifetime (year).

The utility avoided supply costs (UASC) were determined according to Eq. (3):

$$
\mathrm{UASC}=\sum_{t=1}^{n} \frac{\mathrm{ASC}_{t}}{(1+i)^{t-1}}
$$

where $\mathrm{ASC}_{t}$ is the net present value of the avoided supply costs for the sponsoring utility in the year $t(€) ; i$ is the interest rate (5\%); and $n$ is the average lifetime (year).

Avoided supply costs for the sponsoring utility do not include pipeline and network costs, since in this case study, the network has plenty of spare capacity. Therefore, in the shortmedium term, these costs are not avoidable by demand-side measures.

In Table 15, the line indicated as "Total" was calculated taking into account the combined effect of measures that target the same end-use. Fuel-switching measures were not included in this analysis, because for this type of measure, it does not make sense to talk about saved natural gas. The impacts caused by the implementation of fuel-switching measures are analysed in Section 6. By observing Table 15, it is possible to conclude that the implementation of the DSM programmes has a very positive economic impact for the utility. The comparison between the cost of saved energy with the NG customer cost shows that implementation of measure 2 (lowflow showerheads) and measure 3 (electronic thermostat) would bring a great benefit to the consumers. The results for measure 1 (solar collectors) and measure 4 (insulation) show that the cost of saved energy is approximately the same as the NG customer cost. 


\section{Results of case studies}

\subsection{Main results for the western central region case study}

Table 16 presents the impacts resultant from the implementation of gas conservation measures, and Table 17 presents the results obtained for fuel-switching measures.

The impacts of implementation of fuel-switching measures are different, since it does not make sense to talk about saved natural gas for consumers. Due to this reason, the following impacts were considered:

- Saved cost for the consumers;

- Payback analysis for the utility (investment/resulting revenues (sales)).

Also a participant test (PT), and a total resource cost test (TRC) were carried out for the western central region case study. The obtained results are also presented in Tables 16 and 17. The lifetimes considered were 15 years for all measures [13], except for low-flow showerheads (10 years) [14], solar water heaters (20 years), and thermal insulation (30 years). An interest rate of 5\% was also considered for this analysis. To calculate the benefits to participants, a fixed cost of $€ 0.61 / \mathrm{m}^{3}$ of natural gas was considered during all equipment lifetime. There are considerable uncertainties in the evolution of gas prices in Western Europe since the prices are linked to the price of oil, whose evolution is very hard to predict. The benefit-cost ratio $\left(\mathrm{BCR}_{\mathrm{p}}\right)$ is the ratio of the total benefits of a programme to the total costs discounted over some specified time

Table 16

Impacts caused by the implementation of the measures to improve gas technologies efficiency

\begin{tabular}{lllll}
\hline Type of impact & $\begin{array}{l}\text { Solar } \\
\text { collector }\end{array}$ & $\begin{array}{l}\text { Low-flow } \\
\text { showerhead }\end{array}$ & $\begin{array}{l}\text { Electronic } \\
\text { thermostat }\end{array}$ & $\begin{array}{l}\text { Double glazing and } \\
\text { protection of joints }\end{array}$ \\
\hline $\begin{array}{l}\text { Saved energy for all the consumers }(\mathrm{MW} \mathrm{h} / \\
\text { year) }\end{array}$ & 6900 & 11700 & 18000 & 2300 \\
Saved cost for the utility ( $€ /$ year) & 140000 & 237000 & 364000 & 47000 \\
Lost revenue for the utility (€/year) & 260000 & 441000 & 679000 & 87000 \\
Reduction of $\mathrm{CO}_{2}$ emissions (tons of $\mathrm{CO}_{2} /$ year) & 1300 & 2750 & 3540 & 500 \\
Participant test (benefit/cost) & 1.1 & $\infty$ & 7.9 & 1.1 \\
Total resource cost test (benefit/cost) & 0.72 & 4.6 & 3.75 & 0.73 \\
\hline
\end{tabular}

Table 17

Impacts caused by the implementation of fuel-switching measures

\begin{tabular}{lllll}
\hline Type of impact & $\begin{array}{l}\text { Gas water } \\
\text { heating }\end{array}$ & $\begin{array}{l}\text { Gas space } \\
\text { heating }\end{array}$ & $\begin{array}{l}\text { Electric heat } \\
\text { pump }\end{array}$ & $\begin{array}{l}\text { Co-generation } \\
\text { in industry }\end{array}$ \\
\hline Saved cost of consumption for the consumers (\%) & 24.3 & 19 & 58 & 35 \\
Simple payback analysis for the consumers (years) & 2.9 & 6.4 & Immediate & 4.6 \\
Simple payback analysis for the utility (years) & 1.7 & 2.4 & Not defined & Not defined \\
Reduction of $\mathrm{CO}_{2}$ emissions (\%) & 36 & 33 & 53 & 15 \\
Participant test (benefit/cost) & 3.66 & 1.70 & Not defined & 2.34 \\
Total resource cost test (benefit/cost) & 3.31 & 1.54 & Not defined & 1.95 \\
\hline
\end{tabular}


period (equipment lifetime), and can be expressed as [15]:

$$
\mathrm{BCR}_{\mathrm{p}}=\frac{B_{\mathrm{p}}}{C_{\mathrm{p}}}
$$

where $\mathrm{BCR}_{\mathrm{p}}$ is the benefit-cost ratio to participants, $B_{\mathrm{p}}$ is the NPV of benefit to participants, $C_{\mathrm{p}}$ is the NPV of costs to participants.

The total resource cost test measures the net costs of a DSM programme as a resource option based on the total costs of the programme, including both the participants' and the utility's costs. Both PT and TRC are applicable to energy-efficiency, load management, and fuel switching programmes. For fuel switching programmes, the test measures the net effect of the impacts from the fuel not chosen versus the impacts from the fuel that is chosen as a result of the programme. Also, the TRC test results for fuel switching should be viewed as a measure of the economic efficiency implications of the total energy supply systems (gas and electric). The benefit-cost ratio $\left(\mathrm{BCR}_{\mathrm{TRC}}\right)$ is the ratio of the discounted total benefits of the programme to the discounted total costs over some specified time period (equipment lifetime), and is expressed as [15]:

$$
\mathrm{BCR}_{\mathrm{TRC}}=\frac{B_{\mathrm{TRC}}}{C_{\mathrm{TRC}}}
$$

where $\mathrm{BCR}_{\mathrm{TRC}}$ is the benefit-cost ratio of the total costs of the resource, $B_{\mathrm{TRC}}$ is the total benefits of the programme, $C_{\mathrm{TRC}}$ is the total costs of the programme.

\subsubsection{Impacts on consumers}

The programme impacts on consumers may be observed in Tables 16 and 17. Concerning the energy efficiency measures, the impacts are described as follows:

Measure 1 (solar water heating assisted by natural gas back-up) would have the highest energy savings per consumer, although it requires a high investment by the participants. Because of the large initial investment, the benefit-cost ratio to participant $\left(\mathrm{BCR}_{\mathrm{p}}\right)$ is around one, which indicates that the implementation of this measure would have a neutral economic impact for the consumers (the consumers would not win or loose money during the equipment lifetime). Energy savings per family in measure 2 are the lowest of all, but consumers would not have to carry out any type of investment, since the distribution utility would offer the low-flow showerhead. Both the simple payback period and the $\mathrm{BCR}_{\mathrm{p}}$ analysis show a very positive economical impact (the $\mathrm{BCR}_{\mathrm{p}}$ is infinite because participants would not have any costs associated with this measure). The thermostat installation (measure 3 ) would also be offered by the gas utility. Measure 3 has a $\mathrm{BCR}_{\mathrm{p}}$ above one, and an attractive payback period, meaning that participants would have profited due to the application of this measure. In measure 4 (sealing of joints and double glazing), the consumers have to pay the measure total investment. This measure is especially oriented to new buildings or retrofitting. In the other cases, the simple payback analysis shows a long payback period. The $\mathrm{BCR}_{\mathrm{p}}$ analysis shows that participants would have a neutral economic impact over the equipment lifetime period, which is 30 years. However, increased thermal and acoustical comfort may justify this measure implementation. 
Concerning the fuel-switching measures, it was found that measure 5 (gas water heater) is economically attractive (payback less than 3 years) and responsible for a significant reduction of consumption costs, as well as $\mathrm{CO}_{2}$ emissions. Measure 6 (gas space heater) produces similar savings but is not so attractive, since participants would need around 6 years to recover their investment. When the specified time period is considered (15 years), the $\mathrm{BCR}_{\mathrm{p}}$ results show that measure 5 (gas water heater) and measure 6 (gas space heater) are both beneficial. However, the benefit-cost relationship for measure 6 is not so attractive, due to its higher initial investment (by participants).

Measure 7 (electric heat pump) consists in assessing relative performance of the use of an electric heat pump and a gas central heating for space heating. It is not expected, of course, that gas utilities would promote this type of measure, but governmental agencies, multiutilities (selling both gas and electricity), and electric utilities should make some effort (e.g. giving incentives to consumers) in order to motivate the residential consumers to install this type of technology in situations when it is cost-effective. The main point of including the electric heat pump measure was to emphasise that it is useful to carry out not only an analysis of using different forms of energy, but also different types of technologies. The investment needed to install an electric heat pump is similar to the investment necessary to install a gas central heating, but the running costs are smaller (about half with a similar reduction in the consumption of primary energy). Several countries in Europe (e.g. The Netherlands, and Switzerland) are promoting this measure with very positive impacts.

An analysis on the industry impacts has shown that the large-scale implementation of cogeneration (measure 9) in the ceramic and glass industry would lead to a reduction of 35\% of the energy costs in these industries. Bearing in mind that around $15 \%$ of industry production costs are related to energy costs, it is possible to conclude that the application of gas co-generation in ceramic and glass industry would lead to a reduction of around $5 \%$ of production costs. This means that the application of measure 9 would contribute to the creation of more competitive industries. Also, observing Table 17, it is possible to conclude that the benefit-cost ratio to the participant is favourable to the application of this measure.

\subsubsection{Impacts on the utility}

Measure 3 (electronic thermostats) is responsible for the highest level of saved costs for the utility. As shown in Table 16, the lost revenue of measure 3 is also the highest of all measures. Measure 2 (low-flow showerheads) also has a significant level of saved costs for the utility. The lost revenue of measure 2 is also considerable. On the other hand, measure 4 has the lowest level of saved costs for the utility, but the lost revenue is also the lowest. To find out which measures may better suit the utility objectives, all the factors analysed during these sections must be considered, together with possible utility incentives, as described in Section 5 of this paper (utility incentives would only be possible if there was new regulatory intervention).

Gas conservation measures are responsible for a reduction of $4.7 \%$ of the sales to residential customers. On the other side, fuel-switching measures are responsible for an increase of $13.3 \%$ of the sales, considering the total universe of gas consumption.

Analysing the combined application of all measures, it is possible to conclude that the gas utility would have a revenue increase of around $11 \%$. The implementation of gas conservation measures would require a regulatory framework as described in Section 5.1 of this paper. 


\subsubsection{Total resource cost test}

As mentioned, the results of the total resource cost test analysis are shown in Tables 16 and 17. Considering the gas conservation measures (Table 16), it is possible to conclude that on a total resource basis, application of measure 2 (low-flow showerhead), and measure 3 (electronic thermostat) are economically attractive. Measure 1 (solar collectors) and measure 4 (insulation) are not economically attractive, since their $\mathrm{BCR}_{\mathrm{TRC}}$ are marginally below one. In Portugal, a residential solar system is very expensive, and tax incentives are very modest. This means that without greater incentives, it will be very difficult to have a massive implementation of these types of technologies.

Concerning fuel-switching measures, the TRC results are presented in Table 17. The implementation of fuel-switching measures would bring economic benefits to both participants and the natural gas utility company.

\subsection{Results of the city of Burg case study}

To weigh the potentials for gas IRP in Portugal, a comparative study was made for the city of Burg in central Germany. The results are presented in Table 18. In Burg, the natural gas penetration on the energy market has reached a high degree of saturation after a decade of building sector modernisation following Germany's unification. Natural gas played a crucial role to substitute almost all coal stoves using brown coal to enhance comfort and reduce air pollution with a modest investment cost.

Another fundamental difference in Burg is the integration of gas, electricity and district heating supply by one single municipal utility. For this company, gas penetration into the electricity market is not of special interest because highest revenues are coming from electricity sales. Fuel switching policy in Burg focuses on competition with fuel oil and coal. Remaining possible fuelswitching measures are promotion of gas hot air heaters and gas radiant heaters in the service sector, mainly for large supermarkets and repair and service sectors. However, since all enterprises have been restructured and modernised after the unification of Germany, new heating systems have been installed recently and further fuel switching options are rather limited to

Table 18

Integration of demand- and supply-side measures in Burg, Germany

\begin{tabular}{|c|c|c|c|c|c|c|}
\hline $\begin{array}{l}\text { DSM } \\
\text { measures }\end{array}$ & $\begin{array}{l}\text { Promotion } \\
\text { activities }\end{array}$ & $\begin{array}{l}\text { Total cost of } \\
\text { measures }(€ / \text { year })\end{array}$ & $\begin{array}{l}\text { Market pen- } \\
\text { etration/year }(\%)\end{array}$ & $\begin{array}{l}\text { No. of house- } \\
\text { holds }(s)\end{array}$ & 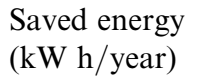 & $\begin{array}{l}\text { Cost/effect }(€ / \\
\mathrm{kW} \text { h gas })\end{array}$ \\
\hline 1 & $1-5$ & 6600 & $<10$ & 500 & 1650000 & 0.004 \\
\hline 2 & $1+5$ & 1320 & $<5$ & 100 & 330000 & 0.004 \\
\hline 3 & $1+5$ & 1920 & $<1$ & 200 & 480000 & 0.004 \\
\hline 4 & $1-5$ & 3323 & 5 & 300 & 830769 & 0.004 \\
\hline
\end{tabular}

Caption: List of DSM measures: 1, heat insulation of external walls in flats with gas heating; 2, heat insulation of roofs; 3 , use of heat protection glazing and sealing of joints; 4 , installation of condensing boilers. List of promotion activities: 1, general advertising/leaflets/brochures; 2, advertising and consultation; 3, education; 4, definition of priority areas for gas supply; 5, tariff reduction for energy savers. 
some new establishing enterprises. Therefore, no special quantifiable programme for fuel switching which exceeds the usual is recommended, already intensive marketing activities for natural gas.

Before natural gas was available, the only option to reduce air pollution was to extend the district heating (DH) system, so all new housing areas are now supplied by this system. However, district heating networks construction requires much more investment than construction of gas pipelines. To avoid the DH system from becoming a stranded cost, the central heating station was switched from brown coal to a natural gas fired CHP plant, which consumes now 38\% of the natural gas supplied to the city of Burg.

In the implementation plan developed, the number of measures per year is set in relation to the number of new clients for gas consumption, which were $2 \%$ in 1998. Most important is the installation of gas condensing boilers, which became the standard solution for heating system modernisation, replacing coal stoves in individual apartments and houses.

The total energy saving effect of the DSM programme is about $2 \%$ of annual gas consumption in Burg, which is remarkable in the situation of market saturation and mostly up-to-date technologies implemented. For the gas utility, the gross lost revenues are almost 7 times higher than the DSM programme cost. When the saved gas purchases are taken into account, the net lost revenues are 3 times higher than the DSM cost. If the DSM programme is continued for 10 years, up to $20 \%$ of gas consumption can be saved. In the absence of incentives, the overall result of the DSM programme in Burg does not generate a large benefit to the gas utility, but with rather limited use of funds a considerable saving of gas could be achieved.

Table 19 gives an overview on the energy and financial effects of the DSM programme suggested for Burg. The total annual savings for gas through this DSM programme amount to 3300 MW h per year.

During the course of the project the gas prices started to follow the sharp increase of oil prices. These variations were more significant than the proposed DSM measures. The local gas distributing company Stadtwerke Burg is operating in a situation where there is already a high market share for gas, and legislation is demanding installation of highly energy efficient systems. Therefore, the remaining potential for additional DSM measures is, fortunately, rather limited.

However, in the coming liberalised gas market, it is possible to consider the introduction of DSM measures in the territories of other competing gas utilities, which can be used as a marketing tool to attract new customers.

Table 19

Impacts caused by the implementation of the measures to improve gas technologies efficiency for city of Burg case study

\begin{tabular}{lcccc}
\hline Type of impact & Measure 5 & Measure 6 & Measure 7 & Measure 8 \\
\hline $\begin{array}{l}\text { Saved energy for all the consumers } \\
\text { (MW h/year) }\end{array}$ & 1650 & 330 & 480 & 831 \\
Saved cost for the utility ( $€ /$ year) & 24750 & 4950 & 7200 & 12461 \\
Lost revenue for the utility (€/year) & 44000 & 8900 & 12900 & 38200 \\
$\begin{array}{l}\text { Reduction of } \mathrm{CO}_{2} \text { emissions } \\
\text { (tons of } \mathrm{CO}_{2} / \text { year) }\end{array}$ & 327 & 65 & 95 & 164 \\
\hline
\end{tabular}




\section{Conclusions}

Natural gas has been introduced in Portugal in the last quarter of 1997, and since then, natural gas consumption has been growing at a very fast rate, showing a good level of acceptance by the consumers. At present, gas consumption in Portugal represents $10 \%$ of the total energy consumption. However, as in many markets, the price of natural gas is attached to the oil price. This price link can make very risky the adoption of natural gas in some applications (e.g. cogeneration).

In order to respond to growing societal and environmental needs, gas distribution utilities should balance their supply options with the possible demand options in order to offer their clients cost-effective energy services instead of just selling $\mathrm{m}^{3}$ of gas. This strategy would allow gas utilities to face the market in a more competitive way and at the same time to operate with a societal perspective. The application of reward and financial mechanisms to promote the implementation of DSM measures is also appropriate to the present situation. The current directive prepared by the EU to promote energy efficient technologies can introduce a social perspective in the market by introducing a suitable regulatory framework to promote cost-effective DSM measures. Incentive policies that would reward the utility effort to avoid the $\mathrm{CO}_{2}$ emissions also seem very appropriate.

For the DSM measures, which were suggested, it is possible to conclude that most of them are beneficial, both to the consumers and to the utility provided there are suitable reward mechanisms as those proposed in Section 5.1.

In the main case study (western central region of Portugal), the suggested implementation plan would lead to a reduction of $4.7 \%$ of natural gas consumption in the residential sector, through the energy efficiency measures. Fuel switching (from other types of energy to natural gas) would increase gas consumption by $13.3 \%$, considering the total universe of consumption. The implementation plan would have a major positive impact on the environment, leading to a significant decrease in the carbon emissions. This case study shows that the installation of new distribution gas networks presents a golden opportunity to introduce cost-effective energyefficient and fuel-switching technologies, since the incremental costs for the improvements are significantly smaller. In mature gas networks, such as in the city of Burg in Germany, the results are more modest, but even so worth pursuing.

\section{References}

[1] De Almeida AT, Lopes A, Carvalho A, Mariano J, Jahn A, Broege M, et al. Natural gas integrated resource planning, SAVE contract $n^{\circ}$ XVII/4.1031/Z/98-055. Brussels: European Commission; 2000.

[2] De Almeida AT, Fonseca P, Saraiva N. An introduction to integrated resource planning. In: Norgard JS, Gula A, De Almeida AT, editors. Development with sustainable use of electricity. Dordrecht: Kluwer Academic Publishers; 1998, p. 49-71.

[3] Gellings CW, Smith WM. Integrating demand-side management into the utility planning. Proceedings of the IEEE 1989;77(6).

[4] Thomas S, Adnot J, Alari P, Irrek W, Lopes C, Nilsson L, et al. Completing the market for least-cost energy services, SAVE contract $n^{\circ}$ XVII/4.1031/Z/98-297. Brussels (Belgium): European Commission; 2000.

[5] Goldman C, Comnes AG, Busch J, Wiel S. Primer on gas integrated resource planning, report LBL-34144. Berkeley (CA): Energy and Environment Division, Lawrence Berkeley Laboratory, University of California; 1993. 
[6] De Almeida AT, Lopes A, Carvalho A. Energy services in Portugal. In: Chesshire JH, editor. From electricity supply to energy services: prospects for active energy services in the European Union. Brussels (Belgium): EURELECTRIC, European Commission; 2000, p. 169-96.

[7] Home energy saving checklist. Pacific Gas and Electric Corporation. Available from: http://www.pge.com/ 003_save_energy/003a_res/003a3g_tips.shtml.

[8] Energy conservation and safety tips. Southern California Gas Company. Available from: http://www. socalgas.com/residential/interactivehome/waterheating.shtml.

[9] International Energy Agency DSM Programme Task Publications. Task VI—Mechanisms for promoting DSM and energy efficiency in changing electricity businesses. International Energy Agency DSM Programme; 2000. Available from: http://dsm.iea.org.

[10] Eto J, Goldmann C, Nadel S. Ratepayer-funded energy-efficiency/programmes in a restructured electricity industry: issues and options for regulators and legislators, report LBNL-41479. Berkeley (CA): Energy and Environment Division, Lawrence Berkeley Laboratory, University of California; 1998.

[11] Kushler M, Suozzo M. Regulating Electric Distribution Utilities as if Energy Efficiency Mattered. Washington (DC): American Council for an Energy-Efficient Economy; 1999.

[12] Meyers S. Improving energy efficiency: strategies for supporting sustained market evolution in developing and transition countries, report LBNL-41460. Berkeley (CA): Energy and Environment Division, Lawrence Berkeley Laboratory, University of California; 1998.

[13] Energy efficiency policy manual, version 1. Sacramento (CA): Energy Division, California Public Utilities Commission; 2001. Available from: http://www.cpuc.ca.gov.

[14] How to buy a water-saving showerhead. Federal Energy Management Program, Office of Energy Efficiency and Renewable Energy, United States Department of Energy; 2000. Available from: http://www.eren.doe.gov.

[15] California standard practice manual: economic analysis of demand-side programs and projects. Sacramento (CA): California Public Utilities Commission; 2001. Available from: http://www.cpuc.ca.gov. 